\title{
Comparison of the effect of ethanol and potassium iodide in antibacterial photodynamic therapy on gram negative pathogens
}

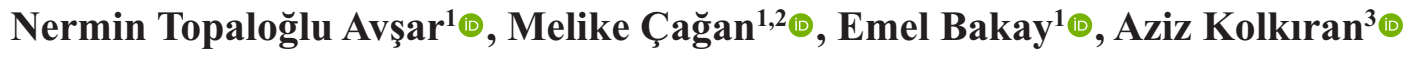 \\ ${ }^{1}$ Department of Biomedical Engineering, Izmir Katip Celebi University, Faculty of Engineering and Architecture, Izmir, Turkey \\ ${ }^{2}$ Department of Bioengineering, Izmir Institute of Technology, Izmir, Turkey \\ ${ }^{3}$ Department of Engineering Sciences, Izmir Katip Celebi University, Faculty of Engineering and Architecture, Izmir, Turkey
}

\begin{abstract}
Objectives: Antibiotics is the most common treatment for bacterial infections. However, bacteria can change their genetic material, develop antibiotic resistance and cannot be treated. This brings the need for new treatment methods. Antibacterial Photodynamic Therapy is becoming a promising approach to treat bacterial infections. It is based on the use of photosensitizer to be activated by light with an appropriate wavelength and it will result in reactive oxygen species which are responsible for the destruction of pathogens. In this study, Antibacterial Photodynamic Therapy was examined for the treatment of Pseudomonas aeruginosa with the help of ethanol and potassium iodide.
\end{abstract}

Methods: The effect of Chlorin e6-based photoinactivation was studied on Multidrug resistant $P$. aeruginosa upon irradiation with $655-\mathrm{nm}$ diode laser. Then ethanol and potassium iodide was added to the mechanism separately to increase the efficacy of photoinactivation. After each application, serial dilution method was used for the determination of viable cells.

Results: Outcomes showed that only Antibacterial Photodynamic Therapy causes a mortality rate of $75 \%$. Addition of ethanol causes a mortality rate of $93 \%$ and addition of potassium iodide causes a mortality rate of 99.9\% with less amount of Chlorin e6 and light dose.

Conclusions: Chlorin-e6 based photoinactivation did not provide high mortality rate on P. aeruginosa. The use of ethanol and potassium iodide increased the effect of photoinactivation. The highest mortality rate was obtained with potassium iodide. It was understood that potassium iodide was a better concomitant agent to increase the bactericidal effect of Antibacterial Photodynamic Therapy on P. aeruginosa.

Keywords: Antibacterial photodynamic therapy, chlorin e6, ethanol, potassium iodide, pseudomonas aeruginosa

$\mathrm{B}^{3}$ acteria are single cell organisms that can infect and contaminate any part of the body. Bacteria are generally classified as gram positive and gram negative. While gram positive bacteria have a thick cell wall, gram negative bacteria have a thin cell wall.
However, gram-negative bacteria are usually more harmful because their cell wall is tighter and their outer membrane is hidden by a capsule. If any treatment is not applied, these bacterial strains can even cause death in progressive stages [1]. The most com-

How to cite this article: Topaloğlu Avşar N, Çağan M, Bakay E, Kolkıran A. Comparison of the effect of ethanol and potassium iodide in antibacterial photodynamic therapy on gram negative pathogens. Eur Res J 2021;7(4):348-355. DOI: 10.18621/eurj.736340

Address for correspondence: Nermin Topaloğlu Avşar, PhD., Assistant Professor, Izmir Katip Celebi University, Faculty of Engineering and Architecture, Department of Biomedical Engineering,, 35620 Balatcik-Cigli, Izmir, Turkey.E-mail: nermin.topaloglu@ikcu.edu.tr, Tel: +90232 3293535/3769, Fax: +902323293999 
mon treatment of infections is the use of antibiotics. But, excessive use and misuse of antibiotics result in multidrug resistance which makes antibiotics become nonfunctional against multidrug resistant bacteria via horizontal gene transfer, mutations, etc. [2].

The resistance of pathogenic microorganisms to antibiotics has led to the search for alternative treatment methods for local infections [3]. A potential alternative is antibacterial photodynamic therapy (aPDT) that is defined as photoinactivation of microorganisms via reactive oxygen species that are produced by photosensitizers (PS) activated with appropriate wavelength of light. The best known advantage of aPDT is that both antibiotic-susceptible and resistant bacterial strains do not resist to photoinactivation and there is no possibility to induce resistance to aPDT after repetitive applications [4].

Strong light absorption capacity and high quantum yield of reactive oxygen species are the desired characteristics of an ideal PSs used in aPDT. Other desired properties are to show low toxicity and target selectivity. The wavelength of the light to be used must be selected according to the absorption spectrum of the PS. If the wavelength of the light reaches its peak value in the absorption spectrum of PS, the effect of the reaction will be high. In order to obtain the ideal therapeutic effect, the energy dose of light and the concentration of PS should be properly optimized during the applications [5]. aPDT leads to progressive lipid peroxidation by free radical attack on bacteria. This leads to cell death by the formation of lipid radicals, the elimination of cellular lipids resulting in oxidative damage to the cells. [4-7].

Chlorin e6 (Ce6) is a second-generation PS which is low toxic, easily synthesized, selectively accumulated in target tissue, and has high photosensitizing efficacy [8-10]. Ce6 absorbs 630-680 nm of wavelengths strongly [10]. For this reason, red part of the visible spectrum is an ideal choice to activate $\mathrm{Ce} 6$ [11]. Besides, the wavelengths around $600-\mathrm{nm}$ is in therapeutic window in which the wavelengths can be safely used for the treatment of various diseases without giving serious harm to the biological tissues. Because of the limited absorption capacity of the biological tissue towards these wavelengths, they can travel deeper inside the biological tissues until its target without losing its energy. These features of the wavelengths in the therapeutic window makes them favorable in the therapeutic light applications $[12,13]$. Ce6 is more effective at destroying gram-positive bacteria, sometimes it needs some additional strategies to overcome problems related to gram-negative species [3]. The use ethanol (EtOH) as an adjuvant can be a good strategy to enhance the effect of PS. It is known that EtOH only at low concentrations $(0.075 \%$ $0.01 \%$ ) slows the growth rate of bacteria in stationary phase [14]. In other studies, unlike water, the use of solvents with less polarity such as EtOH enhances the effect of aPDT on biofilms [15]. In the direction of this information, the use of $\mathrm{EtOH}$ as an adjuvant was thought to provide an advantage to increase the effect of PS.

Another possibility to potentiate the effect of aPDT is the addition of inorganic salt during applications. One of these inorganic salts is potassium iodide (KI). It has been shown that the mechanism of action of KI involves electron transfer reactions to produce iodine and molecular radicals [16]. KI could also potentiate aPDT to produce more reactive species [17]. This reaction seems to have singlet oxygens to produce peroxy iodide, which is subsequently converted into molecular iodine and hydrogen peroxide. A mixture of extracellular free iodine, and reactive iodine radicals causes bacterial killing depending on the degree of PS binding to the microbial cells [18]. In brief, $\mathrm{KI}$ can potentiate the effect of photoinactivation of microorganisms. If the PS can bind to the microbial cells and be activated by light absorption in the presence of $\mathrm{KI}$, this mechanism results in short lived reactive iodine species and then molecular iodine produced as a result of singlet oxygen-mediated oxidation of iodide causes bacterial killing [19].

The aim of this study was to investigate and compare the effect of EtOH and KI on the photoinactivation of Pseudomonas aeruginosa in the presence of Ce6 irradiated by $655-\mathrm{nm}$ diode laser.

\section{METHODS}

In this study, photoinactivation efficacy of Ce6 and 655-nm diode laser was examined on multidrug resistant $P$. aeruginosa strain. Then EtOH and KI was used to increase the bactericidal effect of aPDT. Here is a list of groups which were formed and analyzed during these experiments. 
1. Control group: The group which not received $\mathrm{Ce} 6, \mathrm{KI}, \mathrm{EtOH}$ and laser treatment

2. Ce6 group: The group incubated only with $\mathrm{Ce} 6$

3. Laser group: The group treated only with laser light

4. KI group: The group incubated only with KI

5. $\mathrm{Ce} 6+\mathrm{KI}$ group: The group incubated with KI and $\mathrm{Ce} 6$

6. EtOH group: The group incubated only with $\mathrm{EtOH}$

7. $\mathrm{Ce} 6+$ EtOH group: The group incubated with $\mathrm{Ce} 6$ solution containing EtOH

8. aPDT group: The group incubated with $\mathrm{Ce} 6$ and irradiated by laser light

9. aPDT + KI group: The group incubated with $\mathrm{Ce} 6$ and $\mathrm{KI}$ and irradiated by laser light

10. aPDT + EtOH: The group incubated with $\mathrm{Ce} 6$ containing $\mathrm{EtOH}$ and then irradiated by laser light.

\section{Bacteria}

Multidrug resistant clinical isolate of $P$. aeruginosa was used as gram negative pathogen. Stock bacteria was incubated in $5 \mathrm{ml}$ Tryptic Soy Broth allowing them to grow overnight at $37^{\circ} \mathrm{C}$. Then they were centrifuged, the supernatant was discarded. Bacterial pellet was dissolved in phosphate buffered saline (PBS) to obtain a concentration of $108 \mathrm{CFU} / \mathrm{ml}$ and this bacterial solution was used in experiments.

\section{Chemicals}

Ce6 (Santa Cruz Biotechnology, Dallas, TX, USA) was used as PS. Fresh solutions in PBS were prepared at specific concentrations before each experiment and kept at dark to prevent photobleaching. 1, 2.5, 250 and $500 \mu \mathrm{M}$ concentrations were examined throughout this study. These concentrations of Ce6 were determined according to our preliminary experiments. EtOH was used as an adjuvant to increase the effect of Ce6. The Ce6 solution was prepared together with absolute EtOH to obtain a solution containing $20 \% \mathrm{EtOH}$. The concentration of EtOH was defined as $20 \%$, because it was proved previously that this concentration was effective to enhance the photodynamic action on pathogens [11]. KI pellets were dissolved in sterile $\mathrm{dH} 2 \mathrm{O}$ to obtain $100 \mathrm{mM} \mathrm{KI}$ solution and it was used as a potentiator in aPDT. Similarly, $100 \mathrm{mM}$ concentration of KI was also proved as a potentiator for the effective photoinactivation of different bacterial species [20].

\section{Laser Device}

In this study, a diode laser (PS4 III.LED, Changchun New Industries Optoelectronics Co. Ltd., Changchun, China) which emits $655-\mathrm{nm}$ of wavelength was used. This wavelength is in the range of the highest absorption band of the Ce6. The output power of this laser device is adjustable and was set to 200 $\mathrm{mW}$ for photoinactivation. Depending on our preliminary experiments, $200 \mathrm{~mW}$ was found quite safe when it was applied alone. For this reason, it was chosen as an output power and the application times were adjusted manually to obtain different values of energy densities $\left(10,25,50,100,150\right.$ and $\left.200 \mathrm{~J} / \mathrm{cm}^{2}\right)$ which was examined during the laser applications.

\section{Experimental Procedure}

In the experiments, each group was studied in 96well plates as 3 samples and repeated at least three times. $50 \mu \mathrm{L}$ bacterial solutions were added to the specific wells where light was irradiated on them. Then;

- $50 \mu \mathrm{L}$ bacterial solution was mixed with equal volume of PBS in Control and only Laser groups.

- $50 \mu \mathrm{L}$ bacterial solution was mixed with $50 \mu \mathrm{L}$ of $\mathrm{Ce} 6$ in only Ce6, Ce6+KI, aPDT and aPDT+KI groups.

- $50 \mu \mathrm{L}$ bacterial solution was mixed with $50 \mu \mathrm{L}$ $\mathrm{KI}$ in only $\mathrm{KI}, \mathrm{Ce} 6+\mathrm{KI}$ and aPDT $+\mathrm{KI}$ groups.

- $50 \mu \mathrm{L}$ bacterial solution was mixed with $50 \mu \mathrm{L}$ Ce6 solution containing 20\% EtOH in only EtOH, $\mathrm{Ce} 6+\mathrm{EtOH}$ and aPDT+EtOH groups.

- The bacteria were incubated with specific solution in each experimental group for 15 minutes.

- Bacterial solutions were treated with laser light in only Laser, aPDT, aPDT $+\mathrm{KI}$ and aPDT $+\mathrm{EtOH}$ groups.

- After each of these applications, viable bacterial cell count was determined by serial dilution method.

\section{Statistical Analysis}

Data collected from each group after colony counting was normalized by the data of control groups. Normalized data were statistically analyzed by two-tailed Student's t-test. A $p$ value which was smaller than 0.05 was determined as statistically significant. 


\section{RESULTS}

The Effect of Different Energy Doses on P. aeruginosa $10,25,50,100,150$ and $200 \mathrm{~J} / \mathrm{cm}^{2}$ energy doses were used in Laser and aPDT groups. First of all, the effect of these energy doses was examined on bacteria without addition of any chemicals. As shown in Figure 1 , the maximum bactericidal effect of only laser irradiation was obtained with $150 \mathrm{~J} / \mathrm{cm}^{2}$ and resulted in approximately $30 \%$ decrease in cell viability. And still none of these results were statistically significant when they were compared with control group (Fig. 1).

\section{The Photoinactivation with Chlorin e6 on P. aerugi- nosa}

Throughout this study different $\mathrm{Ce} 6$ concentration $(1,2.5,250$ and $500 \mu \mathrm{M})$ was examined in aPDT groups. The maximum mortality rate was obtained with $500 \mu \mathrm{M} \mathrm{Ce} 6$ concentration. It reduced the cell viability nearly $50 \%$ and only this concentration showed a significant bactericidal effect (Fig. 2). In aPDT groups, 250 and $500 \mu \mathrm{M} \mathrm{Ce} 6$ were studied together with $50,100,150$ and $200 \mathrm{~J} / \mathrm{cm}^{2}$ of energy doses. 100 $\mathrm{J} / \mathrm{cm}^{2}$ of energy dose together with $500 \mu \mathrm{M}$ Ce6 provided maximum photoinactivation of $P$. aeruginosa. As shown in Figure. 2, the maximum reduction in bacterial cell viability with $100 \mathrm{~J} / \mathrm{cm}^{2}$ of energy dose and $500 \mu \mathrm{M}$ Ce6 was nearly $75 \%$. This effect was quite high when compared with other parameters that was used and it resulted in a statistical significant reduction

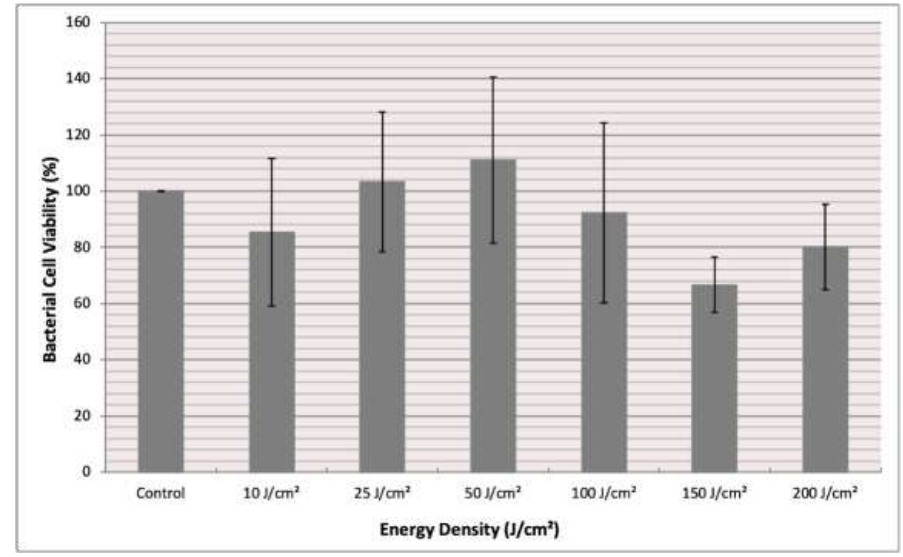

Fig. 1. Effect of light doses on the viability of bacterial cells. Cell viability for $\boldsymbol{P}$. aeruginosa strains was assessed by colony counting after only laser applications and the number of viable cells was normalized with control group (Light dose: 10, $25,50,100,150$, and $200 \mathrm{~J} / \mathrm{cm} 2)$. * shows the statistical significance with respect to control group $(p \leq \mathbf{0 . 0 5})$. when compared with the control group. Unexpectedly, higher energy doses with the same $\mathrm{Ce} 6$ concentration did not provide similar or higher bactericidal effect (Fig. 2).

\section{The effect of Ethanol in Photoinactivation with Ce6 on $P$. aeruginosa}

Ce6 solution was mixed with absolute EtOH to obtain $250 \mu \mathrm{M}$ Ce 6 concentration in a $20 \%$ EtOH solution. The effect of this combination was examined together with 4 different laser energy doses $(50,100$, 150 and $200 \mathrm{~J} / \mathrm{cm}^{2}$ ). 20\% EtOH solution decreased bacterial cell viability nearly $55 \%$. When it was mixed with $250 \mu \mathrm{M} \mathrm{Ce} 6$, its bactericidal effect was not high as in the group of $20 \%$ EtOH only and both of these groups resulted in significant effects. Then this solution was used in aPDT groups. Maximum reduction was obtained with an energy dose of $200 \mathrm{~J} / \mathrm{cm}^{2}$ that resulted in $93 \%$ cell death and it was a statistical significant antibacterial effect (Fig. 3).

\section{The effect of Potassium Iodide in Photoinactivation with Ce6 on P. aeruginosa}

In the last part of this study, $100 \mathrm{mM} \mathrm{KI}$ was used as a source reactive oxygen/iodine species to increase the effect of aPDT with Ce6. In the aPDT+KI group, firstly 500 and $250 \mu \mathrm{M} \mathrm{Ce} 6$ concentrations were used together with 100 and $200 \mathrm{~J} / \mathrm{cm}^{2}$ light energy doses re-

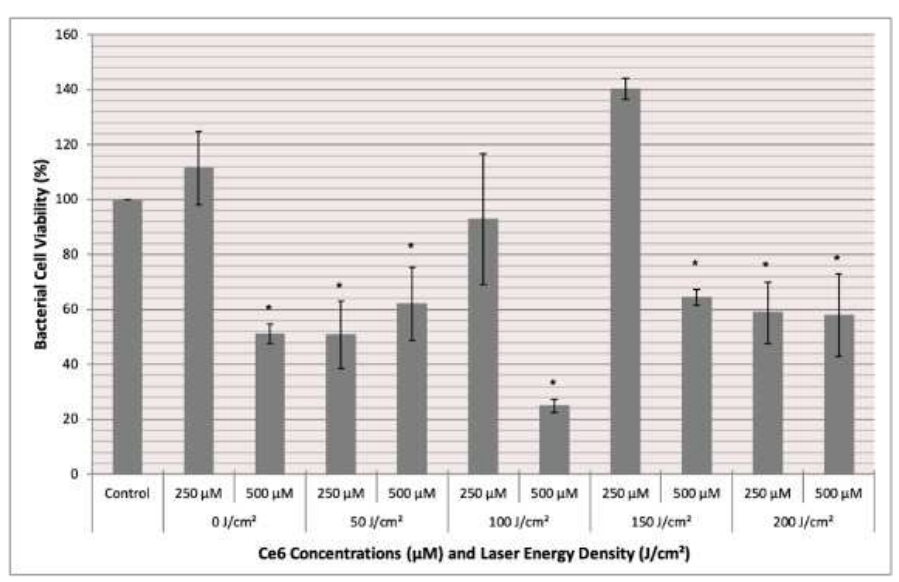

Fig. 2. Effect of Ce6 concentrations and PDT parameters on the viability of bacterial cells. Cell viability for $P$. aeruginosa strains was assessed by colony counting after $\mathrm{Ce} 6$ only and PDT applications and the number of viable cells in each experimental group was normalized with control group (Light dose: 50, 100, 150, and $200 \mathrm{~J} / \mathrm{cm} 2$ and $\mathrm{Ce} 6$ concentrations: 250 and $500 \mu \mathrm{M}$. * shows the statistical significance with respect to control group $(p \leq \mathbf{0 . 0 5})$. 


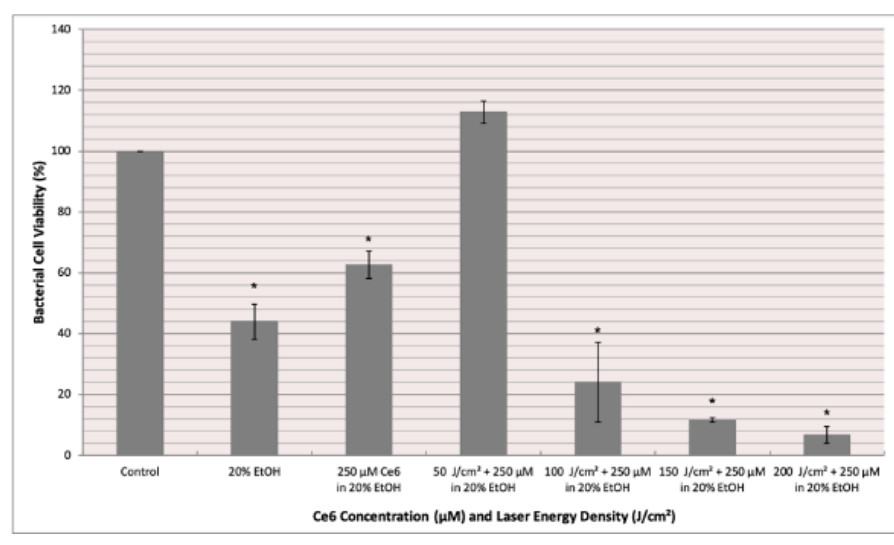

Fig. 3. Effect of 20\% EtOH, $250 \mu \mathrm{M}$ Ce6 in $20 \%$ EtOH and different PDT-EtOH parameters on the viability of bacterial cells. Cell viability for $P$. aeruginosa strains was assessed by colony counting after EtOH only, $250 \mu \mathrm{M} \mathrm{Ce6}$ in $20 \%$ EtOH only and PDT-EtOH applications and the number of viable cells in each experimental group was normalized with control group (Light dose: 50, 100, 150, and $200 \mathrm{~J} / \mathrm{cm} 2$ and Ce6 concentration: $250 \mu \mathrm{M})$. * shows the statistical significance with respect to control group $(p \leq 0.05)$

spectively. These applications resulted in $100 \%$ mortality rate (data not shown). To find the optimum parameters that cause nearly $99.9 \%$ with nontoxic Ce6 concentration and lower energy doses, these parameters were decreased to 1 and $2.5 \mu \mathrm{M} \mathrm{Ce} 6$ and 10 and $25 \mathrm{~J} / \mathrm{cm} 2$ energy doses and used together with 100 $\mathrm{mM} \mathrm{KI}$. As shown in Figure 4, $1 \mu \mathrm{M}$ Ce6 was examined with 10 and $20 \mathrm{~J} / \mathrm{cm} 2$ energy dose. These applications resulted in more than $98 \%$ decrease in cell viability (Fig. 4).

Then the concentration of $\mathrm{Ce} 6$ was increased to $2.5 \mu \mathrm{M}$ and used with 10 and $20 \mathrm{~J} / \mathrm{cm}^{2}$ energy dose in the presence of $100 \mathrm{mM} \mathrm{KI}$. The effect of $2.5 \mu \mathrm{M} \mathrm{Ce} 6$ with $10 \mathrm{~J} / \mathrm{cm}^{2}$ energy dose in the presence of $100 \mathrm{mM}$ KI was again $98 \%$. The highest mortality rate was observed with $99.97 \%$ when $25 \mathrm{~J} / \mathrm{cm}^{2}$ of energy dose used together with $2.5 \mu \mathrm{M}$ Ce6 in the presence of 100 $\mathrm{mM}$ KI. The effect of $100 \mathrm{mM}$ KI with and without these $\mathrm{Ce} 6$ concentrations showed no bactericidal effect (Fig. 5).

\section{DISCUSSION}

aPDT has become a promising tool to combat bacterial infections recently and Ce6 has many advantageous characteristics against pathogens which has

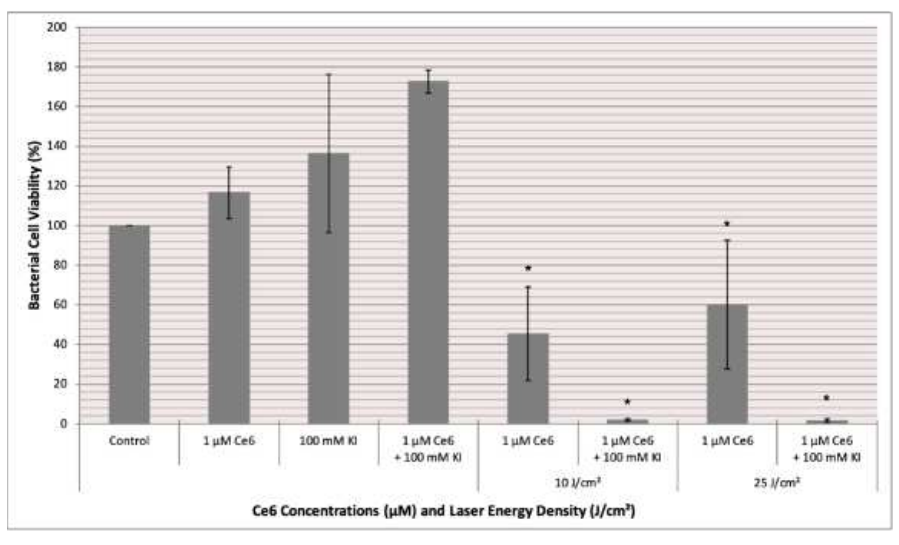

Fig. 4. 4. Effect of $100 \mathrm{mM} \mathrm{KI}, 1 \mu \mathrm{M}$ Ce6 and different PDTKI parameters on the viability of bacterial cells. Cell viability for $P$. aeruginosa strains was assessed by colony counting after $100 \mathrm{mM}$ KI only, $1 \mu \mathrm{M}$ Ce6 in PBS only and PDT-KI applications and the number of viable cells in each experimental group was normalized with control group (Light dose: 10 and $25 \mathrm{~J} / \mathrm{cm} 2$, Ce6 concentration: $1 \mu \mathrm{M}$ and $\mathrm{KI}$ concentration: $100 \mathrm{mM}) .{ }^{*}$ shows the statistical significance with respect to control group $(p \leq \mathbf{0 . 0 5})$

been proved in many studies [21]. Therefore, aPDT with Ce6 was examined in this study for the treatment of gram-negative pathogens which is hard to be destroyed and need higher doses of PS and light intensities to be photoinactivated [22]. When the low concentrations of Ce6 were evaluated on $P$. aerugi$n o s a$, they did not exhibit any dark toxicity. But 500

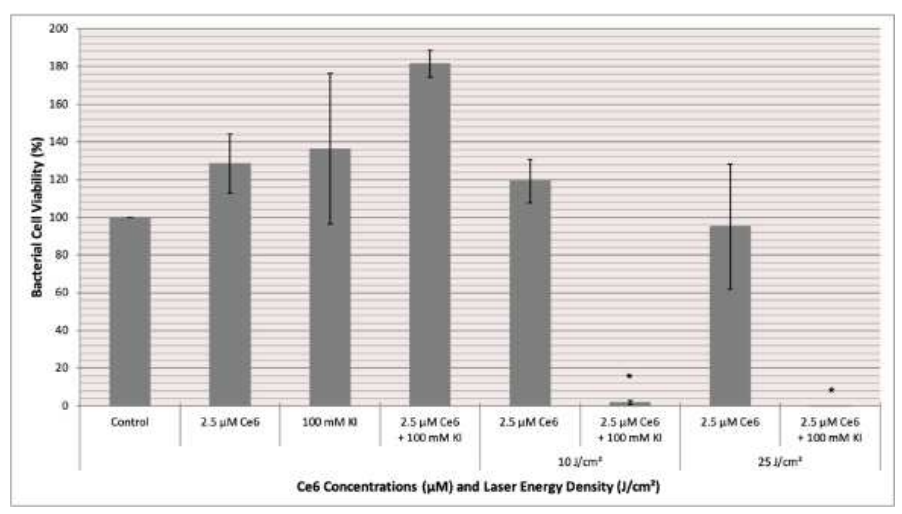

Fig. 4. Effect of 100 mM KI, 2.5 $\mu$ M Ce6 and different PDTKI parameters on the viability of bacterial cells. Cell viability for $P$. aeruginosa strains was assessed by colony counting after $100 \mathrm{mM}$ KI only, 2.5 $\mu \mathrm{M}$ Ce6 in PBS only and PDT-KI applications and the number of viable cells in each experimental group was normalized with control group (Light dose: 10 and $25 \mathrm{~J} / \mathrm{cm} 2$, Ce6 concentrations: $2.5 \mu \mathrm{M}$ and $\mathrm{KI}$ concentration: $100 \mathrm{mM}) .{ }^{*}$ shows the statistical significance with respect to control group $(p \leq \mathbf{0 . 0 5})$ 
$\mu \mathrm{M} \mathrm{Ce} 6$ caused nearly $50 \%$ reduction in cell viability which can be considered as a high dark toxicity and this cannot support idea of aPDT with less side effect in neighboring areas of biological tissues [23].

On the other hand, only laser light with various intensities ranging from 10 to $200 \mathrm{~J} / \mathrm{cm}^{2}$ did not result in meaningful reduction in the cell viability. The maximum mortality rate of $35 \%$ was obtained at the light energy dose of $150 \mathrm{~J} / \mathrm{cm}^{2}$. Thus, it can be explained that only laser application was not harmful on bacterial cell viability and it is a well-known characteristics of red light on cells [24].

Although the use of $\mathrm{Ce} 6$ was a promising drug in aPDT applications [3], our experiments showed that it was ineffective on the multidrug resistant $P$. aeruginosa strain. Even though light energy dose and drug concentration were increased in serious amounts, killing more than $99 \%$ was not obtained. The maximum reduction in cell viability nearly $75 \%$ was reached in the application of $100 \mathrm{~J} / \mathrm{cm}^{2}$ light dose and $500 \mu \mathrm{M}$ Ce6 concentration (Fig. 2). According to many studies, it is shown that Gram negative bacteria opposed to aPDT due to their special wall structure [25-27]. Gram negative bacteria have a complicated many layered and hard-spun outer barrier structures [28]. This barrier excludes most of the PS, thus certain methods have to be used to confirm that PS can penetrate the bacteria and be effective on them [27]. $P$. aeruginosa strain which was used in this study cannot be destroyed efficiently solely using Ce6 in aPDT application. Therefore, this therapy needed some concomitant agents to amplify its activity.

Firstly, the effect of EtOH was examined as an adjuvant in order to increase the effect of the PS. The goal in this part of the study was to reduce the the drug concentration in a serious manner and achieve a mortality rate over $99 \%$. 20\% EtOH was chosen as a concentration to act as an adjuvant in aPDT application. Its antibacterial effect without $\mathrm{Ce} 6$ and light application was not significant, but still quite high. It reduced bacterial cell viability approximately $55 \%$. Although an important decrease (around 93\%) in cell viability with $20 \% \mathrm{EtOH}$ in aPDT was obtained with the parameters of $200 \mathrm{~J} / \mathrm{cm} 2$ energy dose and $250 \mu \mathrm{M} \mathrm{Ce} 6$, sufficient amount of antibacterial effect cannot be achieved (Fig. 3). The only advantage of using 20\% $\mathrm{EtOH}$ as an adjuvant was to reduce the concentration of Ce6 to its half. The light dose has been increased to
$200 \mathrm{~J} / \mathrm{cm} 2$ when this was compared with only aPDT application. Using EtOH against P.aeruginosa raised antimicrobial effect of aPDT. This application exerts antibacterial activity including more production of singlet oxygen, destroying bacterial membrane, rapid denaturation of proteins, causing to cell lysis [29, 30]. But still the energy dose and PS concentration were quite high in this application.

Since the desired outcomes were not achieved in the applications of only aPDT and aPDT+EtOH, KI was examined as a potentiator at the last part of this study. Purpose of using KI was to increase effectiveness of PS for the production of more radical ions. For this reason, $100 \mathrm{mM} \mathrm{KI}$ concentration was chosen as an optimum parameter after literature survey [16-19]. When the effects of only KI and KI together with Ce6 were studied, the results showed that they had no lethal effects on the bacteria. Only KI treatment has increased the bacterial cell viability with a rate of $32 \%$ instead. Then, the effect of 100 and $200 \mathrm{~J} / \mathrm{cm} 2$ light dose and 500 and $2500 \mu \mathrm{M}$ ce 6 concentrations respectively was evaluated together with $100 \mathrm{mM} \mathrm{KI}$. This resulted in $100 \%$ mortality rate (data not shown). Then the concentration of $\mathrm{Ce} 6$ and light dose were reduced to obtain optimum energy dose and PS concentration for achieving a mortality rate of $99.9 \%$. The highest mortality rate was $99.9 \%$, when $25 \mathrm{~J} / \mathrm{cm} 2$ light dose and $2.5 \mu \mathrm{M}$ Ce6 were used together with $100 \mathrm{mM} \mathrm{KI}$ (Fig. 5). Results showed that nontoxic inorganic salt KI potentiates aPDT by increasing the effectiveness of $\mathrm{Ce} 6$ which was proved previously with different types of PSs on different strains of bacteria [17, 31, 32]. The presence of KI forms short-lived reactive iodine species and they induce the generation of more reactive species. Then these reactive iodine species damage bacterial cells $[32,33]$. Use of $100 \mathrm{mM} \mathrm{KI}$ provides the opportunity to decrease the level of energy dose and PS concentration in serious levels. So, it eliminates the risk of dark toxicity and photodestruction depending upon the use of high level of PS and light dose.

\section{CONCLUSION}

Although different light doses of 655-nm of wavelength and Ce6 concentrations were used in Ce6-based photoinactivation and their levels were increased quite 
high values, it did not show efficient bactericidal effect on multidrug resistant $P$. aeruginosa. Therefore, EtOH was used as an adjuvant in aPDT applications to increase the mortality rate. Serious mortality rate was obtained, but it was still not sufficient and the parameters used were still high which may cause cytotoxicity on healthy cells. Then, KI was used as a potentiator in aPDT applications. Over $99.9 \%$ mortality rate was obtained with the help of KI. When results of each three different applications were examined, the use of KI resulted in a significant reduction in light dose (4 $\times$ reduction $)$ and drug concentration $(200 \times$ reduction $)$ by achieving high killing capability on $\mathrm{P}$. aeruginosa which is multidrug resistant gram negative strain.

\section{Authors' Contribution}

Study Conception: NTA, MÇ, EB, AK; Study Design: NTA, MÇ, EB, AK; Supervision: NTA, MÇ, EB, AK; Funding: NTA, AK; Materials: NTA, AK; Data Collection and/or Processing: NTA, MÇ, EB; Statistical Analysis and/or Data Interpretation: NTA, MÇ, EB; Literature Review: NTA, MÇ, EB; Manuscript Preparation: NTA, MÇ, EB, AK and Critical Review: NTA, MÇ, EB, AK.

\section{Conflict of interest}

The authors disclosed no conflict of interest during the preparation or publication of this manuscript.

\section{Financing}

This study was supported by the İzmir Katip Çelebi University Scientific Research Projects (2015ÖNP-MÜMF-0017 to N.T.).

\section{Acknowledgements}

The authors thank Nesrin Horzum Polat, Fatma İbiş, and Nur Çobanoğlu for their help and valuable opinions.

\section{REFERENCES}

1. Dhar AD. Overview of Bacterial Skin Infections. Merck Manual available at: www.merckmanuals.com/home/skindisorders/bacterial-skin-infections/overview-of-bacterial-skin-inf ections. Accessed July 20, 2018.

2. Blair JM, Webber MA, Baylay AJ, Ogbolu DO, Piddock LJ. Molecular mechanisms of antibiotic resistance. Nat Rev Microbiol 2015;13:42-51.
3. Park JH, Moon YH, Bang IS, Kim YC, Kim SA, Ahn SG, et al. Antimicrobial effect of photodynamic therapy using a highly pure chlorin e6. Lasers Med Sci 2010;25:705-10.

4. Liu Y, Qin R, Zaat SA, Breukink E, Heger M. Antibacterial photodynamic therapy: overview of a promising approach to fight antibiotic-resistant bacterial infections. J Clin Transl Sci 2015;1:140

5. Nagata JY, Hioka N, Kimura E, Batistela VR, Terada RSS, Graciano AX, et al. Antibacterial photodynamic therapy for dental caries: evaluation of the photosensitizers used and light source properties. Photodiagnosis Photodyn Ther 2012;9:122-31.

6. Sies H. Oxidative stress: a concept in redox biology and medicine. Redox Biol 2015;4:180-3.

7. Repetto M, Boveris A, Semprine J. Lipid peroxidation: chemical mechanism, biological implications and analytical determination. In: Lipid Peroxidation, Catala A, ed. IntechOpen 2012;1:3-30.

8. Kostenich GA, Zhuravkin IN, Zhavrid EA. Experimental grounds for using chlorin $\rho 6$ in the photodynamic therapy of malignant tumors. J Photochem Photobiol B 1994;22:211-7.

9. Ryu AR, Wang YY, Lee MY. Differential protein expression associated with photodynamic therapy using chlorin e6. Mol Cell Toxicol 2014;10:423-31.

10. Park H, Na K. Conjugation of the photosensitizer Chlorin e6 to pluronic F127 for enhanced cellular internalization for photodynamic therapy. Biomaterials 2013;34:6992-7000.

11. Topaloğlu Avşar N, Bakay E, Kolkıran A. Photodynamic action of chlorin e6 against methicillin resistant staphylococcus aureus with the aid of ethanol. Arch Clin Exp Med 2020;5:100-5.

12. Niemz MH. Laser-Tissue Interactions: Fundamentals and Applications. Springer International Publishing, Berlin, 2019:15-18. 13. Topaloglu N, Özdemir M, Çevik ZBY. Comparative analysis of the light parameters of red and near-infrared diode lasers to induce photobiomodulation on fibroblasts and keratinocytes: an in vitro study. Photodermatol Photoimmunol Photomed 2021;37:253-62.

14. Chatterjee I, Somerville GA, Heilmann C, Sahl HG, Maurer HH, Herrmann M. Very low ethanol concentrations affect the viability and growth recovery in poststationary-phase Staphylococcus aureus populations. Appl Environ Microbiol 2006;72:2627-36.

15. George S, Kishen A. Photophysical, photochemical, and photobiological characterization of methylene blue formulations for light-activated root canal disinfection. $\mathrm{J}$ Biomed Opt 2007; 12:034029.

16. Vecchio D, Gupta A, Huang L, Landi G, Avci P, Rodas A, et al. Bacterial photodynamic inactivation mediated by methylene blue and red light is enhanced by synergistic effect of potassium iodide. Antimicrob Agents Chemother 2015;59:5203-12.

17. Wen X, Zhang X, Szewczyk G, El-Hussein A, Huang YY, Sarna T, et al. Potassium iodide potentiates antimicrobial photodynamic inactivation mediated by rose bengal in in vitro and in vivo studies. Antimicrob Agents Chemother 2017;61:e00467-17. 18. Huang L, Szewczyk G, Sarna T, Hamblin MR. Potassium iodide potentiates broad-spectrum antimicrobial photodynamic inactivation using Photofrin. ACS Infect Dis 2017;3:320-8.

19. Huang L, El-Hussein A, Xuan W, Hamblin MR. Potentiation 
by potassium iodide reveals that the anionic porphyrin TPPS 4 is a surprisingly effective photosensitizer for antimicrobial photodynamic inactivation. J Photochem Photobiol B 2018;178:27786.

20. Ghaffari S, Sarp ASK, Ruhi MK, Gulsoy M. A comparative analysis of aPDI effect of phenothiazinium dyes in presence of inorganic salt as potentiator. Proc. SPIE 10479, Light-Based Diagnosis and Treatment of Infectious Diseases, 2018:1047914.

21. Sperandio F, Huang YY, Hamblin MR. Antimicrobial photodynamic therapy to kill Gram-negative bacteria. Recent Pat Antiinfect Drug Discov 2013;8:108-20.

22. Topaloglu N, Gulsoy M, Yuksel S. Antimicrobial photodynamic therapy of resistant bacterial strains by indocyanine green and 809-nm diode laser. Photomed Laser Surg 2013;31:155-62. 23. Topaloglu N, Guney M, Aysan N, Gulsoy M, Yuksel S. The role of reactive oxygen species in the antibacterial photodynamic treatment: photoinactivation vs proliferation. Lett Appl Microbiol 2016;62:230-6.

24. George S, Kishen A. Advanced noninvasive light-activated disinfection: assessment of cytotoxicity on fibroblast versus antimicrobial activity against Enterococcus faecalis. J Endod 2007;33:599-602.

25. Malik Z, Hanania J, Nitzan Y. New trends in photobiology bactericidal effects of photoactivated porphyrins--An alternative approach to antimicrobial drugs. J Photochem Photobiol B 1990;5:281-93.

26. Nitzan Y, Gutterman M, Malik Z, Ehrenberg B. Inactivation of gram-negative bacteria by photosensitized porphyrins. Photochem Photobiol 1992;55:89-96.

27. Malik Z, Ladan H, Nitzan Y. Photodynamic inactivation of gram-negative bacteria: problems and possible solutions. J Photochem Photobiol B 1992;14:262-6.

28. Hancock RE. The bacterial outer membrane as a drug barrier. Trends Microbiol 1997;5:37-42.

29. Prochnow EP, Martins MR, Campagnolo CB, Santos RC, Villetti MA, Kantorski KZ. Antimicrobial photodynamic effect of phenothiazinic photosensitizers in formulations with ethanol on Pseudomonas aeruginosa biofilms. Photodiagnosis Photodyn Ther 2016;13:291-6.

30. McDonnell G, Russell AD. Antiseptics and disinfectants: activity, action, and resistance. Clin Microbiol Rev 1999;12:14779.

31. Costa RO, Macedo PMD, Carvalhal A, Bernardes-Engemann AR. Use of potassium iodide in dermatology: updates on an old drug. An Bras Dermatol 2013;88:396-402.

32. Agazzi ML, Ballatore MB, Reynoso E, Quiroga, ED, Durantini EN. Synthesis, spectroscopic properties and photodynamic activity of two cationic BODIPY derivatives with application in the photoinactivation of microorganisms. Eur J Med Chem 2017;126:110-21.

33. Zhang Y, Dai T, Wang M, Vecchio D, Chiang LY, Hamblin MR. Potentiation of antimicrobial photodynamic inactivation mediated by a cationic fullerene by added iodide: in vitro and in vivo studies. Nanomedicine 2015;10:603-14. 